\title{
Corela
}

Cognition, représentation, langage

HS-24 | 2018

Multicultural Spoken English

\section{Stress Assignment in Italian Loanwords in English and its Impact on the Stressing of Foreign Words by Native English Speakers}

\section{Fournier Pierre}

\section{(2) OpenEdition \\ Journals}

Electronic version

URL: http://journals.openedition.org/corela/5113

DOI: $10.4000 /$ corela.5113

ISSN: 1638-573X

Publisher

Cercle linguistique du Centre et de I'Ouest - CerLICO

\section{Electronic reference}

Fournier Pierre, "Stress Assignment in Italian Loanwords in English and its Impact on the Stressing of Foreign Words by Native English Speakers », Corela [Online], HS-24 | 2018, Online since 19 June 2018, connection on 01 May 2019. URL : http://journals.openedition.org/corela/5113 ; DOI : 10.4000/ corela. 5113

This text was automatically generated on 1 May 2019.

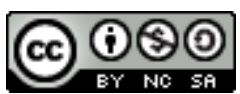

Corela - cognition, représentation, langage est mis à disposition selon les termes de la licence Creative Commons Attribution - Pas d'Utilisation Commerciale - Partage dans les Mêmes Conditions 4.0 International. 


\section{Stress Assignment in Italian Loanwords in English and its Impact on the Stressing of Foreign Words by Native English Speakers}

Fournier Pierre

\section{Introduction'}

1 Stress investigations concerning languages in contact have already been led within the Loan Phonology approach (Kentowicz \& Sohn 2001, Friesner 2009, Svensson 2001, 2004, 2007, Schultz 2013 or P. Fournier 2016). These studies analyse the different ways borrowings can be phonetically or phonologically reproduced when being transferred from source languages to target languages. Two major tendencies are to be found. The loanwords may adapt to the phonological properties of the target language and thus develop assimilatory mechanisms depending on their degrees of integration, or, they may conserve certain phonological characteristics of the source language. As far as stress assignment is concerned, previous results (P. Fournier to appear) demonstrated that Italian loanwords in English systematically reproduced their original Italian stress patterns, and thus, constitute a perfect example of stress conservation. This analysis was dictionary-based, and therefore, the goal of this study is first, to extend the corpus of Italian loanwords by including the Oxford English Dictionary database, in order to test the stress preservation principle on a larger corpus, and second, to confront these results with oral data. An experiment was carried out with English native speakers who were asked to read Italian words aloud, inserted into lists of English words, and it appeared that the stress conservation rate grew in accordance with the speakers' fluency in Italian. This leads us to formulate a hypothesis concerning the way loanwords are integrated into dictionary sources in English, and provides us with insight concerning native English speakers' perception and production of the stressing of loanwords. 
2 The second part focuses on the stress patterns of Italian loanwords in English dictionaries and investigates the potential stress match between the two languages.

\section{Stress assignment of Italian loanwords in English pronunciation dictionaries}

\subsection{Corpus building}

3 The final corpus is based on the data of three major references in English: the Oxford English Dictionary (henceforth OED), the Longman Pronunciation Dictionary (henceforth LPD) and the Cambridge English Pronouncing Dictionary (henceforth EPD). The last two sources are reference works concerning English pronunciation while the OED gives access, through its large database, to numbers of representative loanwords. The loanwords extracted from the OED also include phonetic transcriptions when they are attested.

The book that was used during the very first steps in collecting samples of representative loanwords is Laura Pinnavaia's major work about the Italian loanwords which are attested in the OED (Pinnavaia 2001). Her mainly lexicographic approach, coupled with a diachronic perspective, turned out to be of great value to elaborate the corpus. She considered the classifications "It.", "adopted from It." or "adapted" as representative of Italian loanwords. Her lists were double-checked to make sure that only real Italian loanwords would be integrated into the final corpus. Only direct ${ }^{2}$ loanwords with a $<\mathrm{VCV} \#>3$ segmental structure have been selected from her lists. Indeed, $<\mathrm{VC}{ }_{2} \mathrm{~V} \#>$ sequences would prevent any possible determination of stress influence since pre-final consonant clusters are determining factors in stress assignment in both languages ${ }^{4}$. The example below illustrates $<-\mathrm{VC}_{2} \mathrm{~V} \#>$ Italian structures turning into $<-\mathrm{VCV} \#>$ English ones.

\begin{tabular}{|l|l|l|}
\hline$<-\mathrm{VC}_{2} \mathrm{V \# >}$ (Italian) & $\rightarrow$ & $<-\mathrm{VCV \# >}$ (English) \\
\hline buratto & $\rightarrow$ & borato \\
\hline
\end{tabular}

5 When the structures of the last two syllables, whose influence on stress assignment appears to be fundamental, are modified through the borrowing process, the corresponding items are not conserved because stress comparison would prove to be vain.

\begin{tabular}{|l|l|l|}
\hline Italian & & English \\
\hline teleferica & $\rightarrow$ & teleferic \\
\hline
\end{tabular}

Despite the OED precious etymological resources, source languages may prove to be difficult to determine. Some loanwords (i.e. pasquinade, mora and moto) have an uncertain origin that might be dual according to the OED. They, therefore, are not selected either. The corpus building is systematically carried out with an etymological double-check, because it turns out that some sections of the OED are currently updated, thus possibly 
modifying the initial data Pinnavaia used in her work. This uncertain etymology is not relevant to our study because only Italian loanwords are taken into account.

7 On the contrary, variant spellings that do not modify $\langle\mathrm{VCV} \#\rangle$ structures in both languages are preserved.

\begin{tabular}{|l|l|l|}
\hline Italian & & English \\
\hline balcone & $\rightarrow$ & balcony \\
\hline cembalo & $\rightarrow$ & cymbalo \\
\hline letterato & $\rightarrow$ & literato \\
\hline
\end{tabular}

8 After having applied these first lexicographic criteria to the lists Pinnavaia built, the resulting list of Italian loanwords is composed of 534 items. However, 89 out of these 534 loanwords are obsolete in the OED. Those outdated loanwords, whose entries do not contain any phonetic information, turn out to be useless and have to be rejected. The entire list of obsolete Italian loanwords is found below:

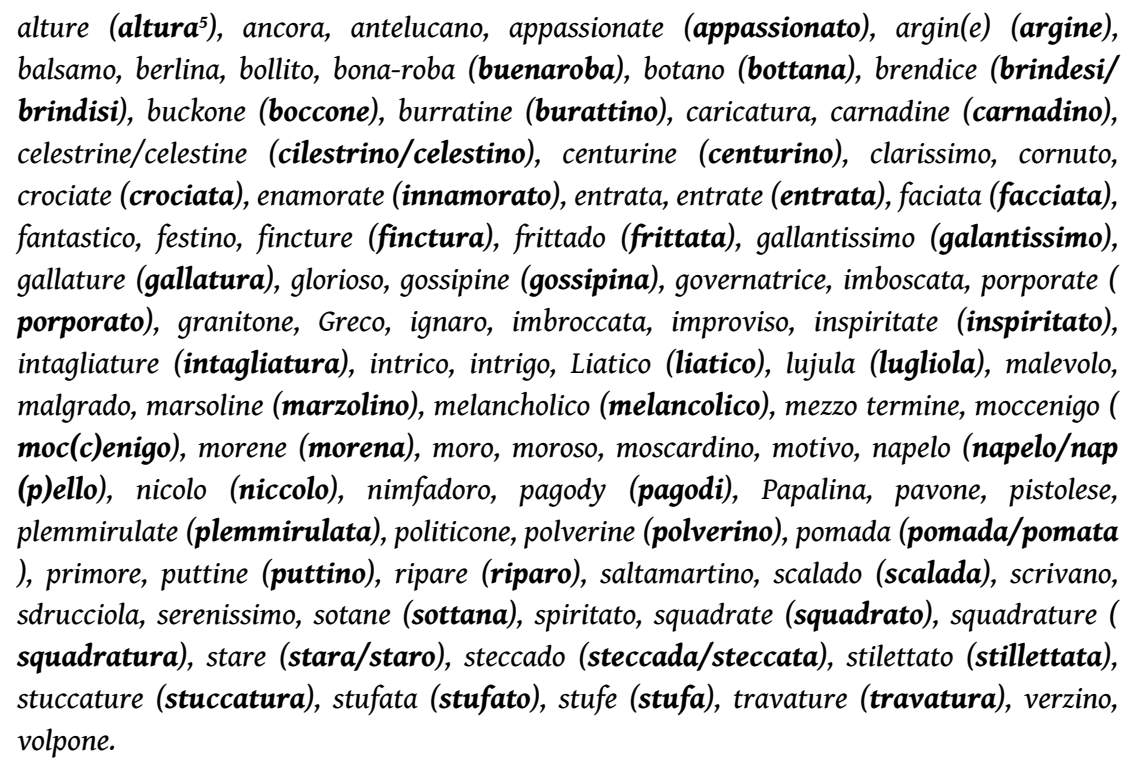

9 The resulting corpus has yet to be cleaned because 45 loanwords attest final mute $<\mathrm{e}>\mathrm{s}$ in English that modify the number of syllables compared to the corresponding Italian terms whose $<\mathrm{e} \#>\mathrm{s}$ are always pronounced. The determination of the stress pattern is then compromised in the perspective of a stress preservation analysis. These 45 English loanwords are found below:

ariose (arioso), belvedere, Bolognese ${ }^{6}$, capitanate (capitanato), Cassinese, Comacine ( comasino), davyne (davina), ergonovine, facellite, Ferrarese, fuse (fuso), galipine ( galipeina), Genovese, Ghibelline (Ghibellino), girasol(e) (girasole), granite (granito), gumfiate (gonfiato), hieratite, impassionate (impassionato), Italianate (italianato), marinate (marinato), matildite, Milanese, miniature (miniatura), nunciature (nunziatura ), pastose (pastoso), perrierite, pilastrade (pilastrata), profile (proffilo), ptomaine ( ptomaina), recitative (recitativo), rosasite, scalade (scalada), scarpine, scope (scopo), sellaite, simetite, sistine (sistina), soldanate (soldanato), taramellite, Ticinese, Torinese, tramontane (tramontana), travertine (travertino), trombone. 

updated yet: it appears that some Italian loanwords do not have any associated phonetic transcriptions. Stress comparison turns out to be impossible and these items have therefore not been retained. The following list includes these 16 cases:

barcone ${ }^{7}$, casal(e), con impeto, granito, latticino/latticinio, natrodavyne (natrodavyna),

sonata da camera, sonata da chiesa, stretto maestrale, verde antico, viola pomposa, violetta marina, violoncello piccolo, vita nuova, inamorate (innamorato), Veronese.

11 The application of the previous criteria makes it possible to reject non-relevant items. The corpus is now made up of 384 loanwords, whose stress patterns are extracted from the three English dictionary sources ${ }^{8}$. Dialect-dependent differences in British English and American English are also taken into account. Collected English stress patterns will, in the second part of the study, be compared with Italian stress patterns. In fact, corresponding Italian words ${ }^{9}$ and their stress patterns have to be investigated. The selected Italian dictionary sources are the Dizionario della Lingua Italiana (Sabatini \& Coletti 2005) and the Le Robert \& Signorelli. Dictionnaire français-italien/italien-français (Arrizi \& Robert 1999). Quite surprisingly, it turns out that 26 Italian loanwords, attested in English dictionaries and classified as such, cannot be found in Italian dictionary sources:

brava, camata, cavo-rilievo, dimity, flautone, gigalira, improvisatrice, intrada, messa di voce, mezza voce, Mona Lisa, Monte di Pietà, negroni, numero uno, oboe d'amore, ottava rima, palmarosa, piano nobile, piano piano, sgraffiato, sgraffito, tarantato, tarentola, terza rima, Unione Siciliana, Verona.

Furthermore, seven Italian loanwords with -ino and -ina diminutive suffixes in English are not attested as such in Italian sources where only deriving forms are found:

duettino (duetto), fantoccini (fantoccio), giallolino (giallo), palombino (palombo), pandurina (pandura), scherzino (scherzo), spaghettini (spaghetto/spaghetti).

Finally, syneresis is a frequent phonetic phenomenon occurring in Italian and the stressed syllables that undergo this process have to be carefully dealt with. Two cases are to be distinguished. The first one is only related to the two Italian dictionary sources into which this phonetic process leads to distinct stress representations. The Dizionario della Lingua Italiana does not include $<\mathrm{i}>$ and its palatalized $/ \mathrm{j} /$ realization within the stressed syllable whereas the Robert \& Signorelli dictionary does.

Dizionario della Lingua Italiana: cappricci'oso, curi'oso, ruffi'ano

Robert \& Signorelli: cappric'cioso, cu'rioso, ruffiano

The inclusion of those items might lead to a misinterpretation of Italian stress patterns and then skew the results of the stress match investigation with English. Indeed, and this is the second case, the borrowing transfer may, in some very specific cases, trigger a resyllabification process that deeply reshapes syllable structures of corresponding Italian loanwords in English and affects the determination of stress patterns. The loanword piano clearly illustrates this phenomenon because in English, <ia> is traditionally interpreted as a syllabically-dissociated sequence that then has to be considered as disyllabic. The expected stress pattern of piano in English is therefore /010/. However, the foreign origin of piano and the potential influence of Italian phonological principles over English create a stress variant in $/ 10 /$ according to which $<\mathrm{i}>$ is palatalized and included in the representation of the stressed syllable. A similar phenomenon occurs with soave, whose <oa> sequence is disyllabic in Italian, hence, its /010/ stress pattern in both Italian dictionaries. However, the alternative phonetic realization of $\langle 0\rangle$ as $/ w /$ in English reshapes its syllable structure in which it is perceived as a monosyllabic sequence. The 
determination of the English stress pattern (/10/ or /100/?) raises insoluble problems. Those 42 cases of conflicting syllabic and stress representations are not integrated into the final corpus:

arioso, basso-relievo (bassorilievo), bersagliere, capriccioso, carabiniere, condottiere ( condot(t)iero), conversazione, curioso, diabolo, duomo, forte-piano, furioso, grazioso, majolica (maiolica), mezza-majolica (mezzamaiolica), mezzo-rilievo (mezzorilievo), millefiore, minchiate, mysterioso (misterioso), Nebbiolo, paolo, passeggiata, pensiero, pensione, piano, quartiere, relievo (rilievo), religioso, ripieno, Riviera, ruffiano, scagliola, scuola, sestiere, Siciliana, soave, stagione, stiacciato, studiolo, suabe (soave), zabaglione ( zabaione), viale.

The final corpus is composed of 309 Italian loanwords (see annex). Gender, singular/ plural or spelling variations are found, but these differences are not relevant as far as stress assignment is concerned.

\section{Italian / English stress match investigation in dictionary sources}

\subsubsection{Stress in Italian}

In Italian, as well as in English, there is a lexical stress (noted /1/). This phonological similarity between both languages makes it possible to compare the stress patterns of loanwords in the source language and in the target language. Several studies concerning stress patterns in Italian have been carried out and the results appear to be equivalent. In Italian, words are mainly stressed on the penultimate syllable (80\%). Stress on the antepenultimate syllable is also attested (16\%) and the final stress pattern is not productive (only 4\%) (Borrelli 2002; Thornton, Iacobini \& Burani 1997). If we compare these results with those based on the stress patterns of the Italian items that constitute our corpus, the general tendency is confirmed. Indeed, out of 309 Italian loanwords:

- 247 are stressed on the penultimate syllable (79.9\%).

- 57 are stressed on the antepenultimate syllable (18.4\%).

-4 are stressed on the final syllable (1.4\%).

-1 case of stress variation is attested $(0.3 \%)$.

\subsubsection{Results}

The comparison of Italian stress patterns with the stress patterns of corresponding Italian loanwords in English proves to be very instructive. Indeed, as Table 1 below shows, most Italian loanwords with $\langle\mathrm{VCV}>>$ structures retain their original stress patterns in English as well. Out of 309 loanwords, $296^{10}$ total stress matches are attested no matter what the original Italian stress patterns may be ${ }^{11}$ (final, penultimate or antepenultimate stress patterns).

\begin{tabular}{|l|l|l|}
\hline $\begin{array}{l}\text { total match } \\
/-\mathbf{1} / \rightarrow /-1 /{ }^{12}\end{array}$ & $\begin{array}{l}\text { total match } \\
/(-) 10 / \rightarrow /(-) 10 /\end{array}$ & $\begin{array}{l}\text { total match } \\
/(-) 100 / \rightarrow /(-) 100 /\end{array}$ \\
\hline 3 & 241 & 52 \\
\hline
\end{tabular}




\begin{tabular}{|l|l|l|}
\hline oi'me $\rightarrow$ oi'me & affetu'oso $\rightarrow$ affettu'oso & al'tissimo $\rightarrow$ al'tissimo \\
romani'ta $\rightarrow$ Romani'tà & do'gana $\rightarrow$ do'gana & 'broccolo $\rightarrow$ 'broccoli \\
terribili'tà $\rightarrow$ terribili'tà & fu'rore $\rightarrow$ fu'rore & e'nergico $\rightarrow$ e'nergico \\
ri'presa $\rightarrow$ ri'presa & 'timpano $\rightarrow$ 'timpani \\
\hline
\end{tabular}

Table 1: Total stress matches between Italian and English

Only 4 loanwords out of 309 do not display any stress match between Italian and English:

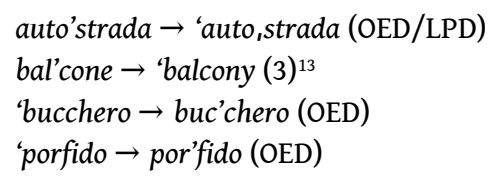

The balcony loanword is interesting, because the original Italian stress pattern is reinterpreted $(/ 100 /)$ and accompanied by a change in spelling (from $<e>$ to $<y>$ ) which highlights the assimilation process this loanword underwent in English. The determination of the stress pattern of autostrada is problematic because it appears to be interpreted as a compound in English with the primary stress being located on the first lexical unit (auto-). A secondary stress is then added on the penultimate syllable ${ }^{14}$, in accordance with the Italian stress pattern. The auto- sequence which is categorized as a highly productive combining form in the compounding domain and that is inherited from Latin, may explain this specific stress pattern. The last two exceptions are only attested in the OED.

21 Finally, nine partial stress matches are observed between Italian and English.

\begin{tabular}{|l|l|}
\hline Italian & English \\
\hline 'bravo & 'bravo /10/ (3) + var /01/ EPD (GB/US'15) \\
\hline ca'sino / casi'no ${ }^{16}$ & ca'sino (3) \\
\hline in'cognita & in'cognita + var /(-)10/ OED \\
\hline in'cognito & incog'nito (3) + var /0100/ (3) \\
\hline 'pergola & 'pergola (3) + var /010/ LPD (GB/US) \\
\hline pie'ta & Pie'tà (3) + 'Pietà LPD/EPD (GB/US in LPD and GB in EPD) \\
\hline 'rapido & 'rapido + var /010/ (GB/US) OED \\
\hline ricer'care & ricer'care + var /1000/ (GB) OED \\
\hline ses'tina & ses'tina + var /100/ (US) OED \\
\hline
\end{tabular}


Table 2: Partial stress matches between Italian and English

As can be observed in Table 2, stress variants are minor in English dictionary sources (9 cases out of 309 loanwords i.e. 2.9\%). Two types of variation are attested in the above table. The variation may be either attested within the same dictionary data base (example: incognita in the OED), or, the variation can be found between dictionaries (example: Pietà, whose alternative stress pattern on the first syllable is attested in the LPD and the EPD but not recognized by the OED).

Furthermore, it is worth noting that dialect-dependent differences have no impact on the stress of Italian loanwords in English. The OED entries have not been fully updated yet and thus access is often only restricted to British phonetic transcriptions, however, stress variants which are linked to dialectal variation are very limited and generally not extended to the three dictionary sources. This means that the dialectal argument plays no part in the stressing of Italian loanwords whose stress patterns are only influenced by the reproduction of the phonological stress properties of Italian. This is a major difference with French loanwords whose stress patterns are greatly influenced by the varieties of English under scrutiny (see P. Fournier 2013 and 2016).

\subsubsection{Preliminary conclusions concerning dictionary data} corresponding Italian loanwords in English demonstrates that the stress pattern of the source language (Italian) is almost always reproduced by the target language (English). The results, i.e. $95.8 \%$ total match added to $2.9 \%$ partial match, strongly support this argument. Only $1.3 \%$ of Italian loanwords are not stressed according to the Italian stress pattern in English and show assimilatory features. Italian loanwords are not stressassimilated in English and the low rate of partial matches confirms that trend.

These results also highlight the reliability of the OED phonetic transcriptions which have often been criticized for a very long time in the specialized literature. Indeed, annex 1 shows that a high proportion of Italian loanwords are only attested in the OED. However, the stress conservation principle is also valid, as the two reference pronouncing dictionaries (i.e. the LPD and the EPD) show. The results of the first study (P. Fournier to appear) are thus confirmed.

The next part of the study compares those results, based on dictionary sources, with oral data. An experiment was conducted with seven English native speakers to determine the influence of the introduction of Italian loanwords on the way Italian loanwords are perceived and stressed in English. The majority of Italian loanwords in English are stressed on the penultimate syllable. The preservation of Italian stress patterns explains why the penultimate stress pattern is the most frequent one. However, the dictionarybased data has proved that words that are stressed on the antepenultimate syllable in Italian also reproduce the same stress pattern in English after the borrowing process. Nonetheless, it turns out that the massive introduction of Italian loanwords, which are stressed on the penultimate syllable, has had an impact on the way foreign words in general might be perceived and stressed by English speakers. 


\section{English native speakers' sensitivity to Italian word stress}

\subsection{Description of the experiment}

Seven English native speakers (two male and five female speakers), aged from 22 to 35, were asked to read a list of items. Several varieties of English were represented (Irish, Scottish, British and American English). This hardly seems relevant, though, as the first part has clearly demonstrated that in English, the stress of Italian loanwords is not determined by the variety under consideration. Five speakers are lecturers in French universities and two of them are prospective EFL teachers. Several of them have advanced language skills abilities and can speak several languages such as French, Spanish, Arabic, German, Turkish or Hebrew, however, only three of them studied Italian at school, although only for one year, at high school or university.

The list of items they were asked to read was composed of 150 words, 50 of which were Italian words (nouns or adjectives). Twenty-six of those Italian items are stressed on the penultimate syllable, while the remaining 24 are stressed on the antepenultimate syllable. Several conditions were implemented in the corpus elaboration. First, the Italian words cannot be loanwords in English and they have to exhibit $\langle\mathrm{VCV}>>$ structures. Words with $<\mathrm{e}$ > structures were not selected because the vocalic realisation or non-realisation might modify syllable structure and thus, the determination of the primary stress location. Moreover, their spellings had to be as far from any similar English word as possible. Lastly, suffixed Italian words (ending in -ino or -ina) were not selected because the morphological parameter, and in particular the suffixal one, is determining in stress assignment in Italian, and English speakers who have linguistic notions concerning Italian might be tempted to apply these stress rules. The goal of this experiment was to test how English speakers stress Italian words, when inserted in a list of English items. The preferential Italian stress patterns, as we have demonstrated in the first part, are /()10/ and /(-)100/. This is why the 50 Italian words have at least three syllables. English speakers were expected to stress Italian words on the penultimate or antepenultimate syllable. Would their stress realisations match with the Italian stress patterns as dictionary sources suggested? It was expected that the match rate would be connected with the informants' command of the Italian language. Here is the list of the selected Italian words:

Italian words in /(-)10/: sagrestano, pericoloso, naftalina, panchina, premurosa, pedina, intriso, vampata, riposo, morboso, grattacapo, gattino, lettino, lattuga, permalosa, pasticcino, velenoso, pendolino, raffinato, effettiva, pettinatura, scanalatura, portafortuna, scriminatura, spaventapasseri, qualcosa.

Italian words in /(-)100/: solita, umido, gomito, prossimo, enfasi, ibrida, ettaro, valvola, ennesimo, gomitolo, edicola, pellicola, ostacolo, ossigeno, novantesimo, voltastomaco, quarantesima, lucertola, garofano, geroglifici, fascicolo, gambero, capitombolo, scampolo.

The other items on the list are English words with different etymological backgrounds. They may be of Romance or Germanic origin and belong to several syntactic categories. Attested loanwords from different languages were also selected in order to ensure that English speakers would not only focus on Italian words that sounded strange to them. The 100 words that constituted the rest of the list are presented below: 
definition, majority, epidemiology, jealousy, laureate, metaphor, imprisonment, ligature, observatory, logarithm, ironing, kingfisher, landholder, latecomer, helplessness, heaviness, livelihood, meadowland, overburden, wintergreen, dynamic, maintainable, heterogeneous, hysterical, juvenile, mandatory, lateral, maturative, lenticular, litigious, handwritten, threatening, meaningless, yellowish, weaponless, uppermost, turnipy, weedgrown, waterproof, tokenistic, indirectly, organically, humanistically, luminously, marginally, pejoratively, meditatively, pronouncedly, monstrously, nutritionally, knowledgeably, tellingly, prettily, heartbreakingly, healthily, girlishly, early, feelingly, wholly, guiltily, individuate, irradiate, obnubilate, licentiate, panegyrize, liquidate, manducate, masculinize, modify, nationalize, wallow, hearten, glisten, fumble, forbid, believe, understand, hurdle, listen, answer, kibbutznik, mandapam, mazurka, pastourelle, restaurant, resumé, gendarmerie, t'ai chi ch'uan, kimono, tokonoma, genipapo, guerilla, gemütlich, gegenschein, kindergarten, dreidel, cunjevoi, couscous, bungalow, smorgasbord.

The speakers were then asked to read the whole list without any further information. The presence of loanwords of different origins which are attested in English along with other English words, and the random order the words were listed, could make the speakers to think that all these words were attested in English. Consequently, they systematically attributed stress patterns no matter the words they were presented with. Data recording was carried out by a single person but oral data analysis and the determination of stress patterns concerning Italian words were treated separately by three researchers. This analysis was first carried out separately and results were then confronted. When the three people could not come to an agreement concerning primary stress location, the majority (two over one) won, but, it only represents a dozen of cases because the determination of stressed syllables is generally made easy by the reading of isolated words. Finally, ten oral productions were rejected, because speakers mispronounced the words or pronounced them so slowly that the stressed syllable identification was made impossible.

\subsection{Results}

\subsubsection{Global results}

31 Each of the 7 speakers pronounced 50 words and only 10 productions - that is 340 tokens could not be used.

\begin{tabular}{|l|l|l|}
\hline stress patterns & occurrences & rate \\
\hline$/(-) 10 /$ & 280 & $82,3 \%$ \\
\hline$/(-) 100 /$ & 57 & $16,8 \%$ \\
\hline$/(-) 1000 /$ & 3 & $0,9 \%$ \\
\hline
\end{tabular}

Table 3: Overall results concerning the stress patterns of Italian words

32 The figures show that English speakers mainly stress Italian words on the penultimate syllable (82\%). The /(-)100/ stress pattern is a fairly productive one as well (16\%) and the $/(-) 1000 /$ stress pattern is clearly not considered as a potential option ${ }^{17}(0.9 \%)$. It is worth noting that the selected speakers never opted for the final stress pattern which 
nevertheless exists in Italian. The goal of this experiment is to check the potential stress match between Italian and English, and to do so, results concerning stress match have to be reorganized according to the Italian primary stress location.

\subsubsection{Stress match analysis between oral data and Italian stress patterns}

If only Italian words that are stressed in /(-)10/ are taken into account, 26 words were pronounced by 7 speakers, and 4 items could not be used, which means 178 occurrences. Among the 24 Italian items that are stressed in /(-)100/, 6 productions could not be used, which means 162 occurrences. The following table examines the distinction between the stress patterns the English speakers realized alongside the stress match investigation criterion.

\begin{tabular}{|l|l|l|l|l|}
\hline \multicolumn{1}{|l|}{} & \multicolumn{2}{l}{$\begin{array}{l}\text { Italian words in } /(- \\
\text { 10/ }\end{array}$} & $\begin{array}{l}\text { Italian words in } /(- \\
100 /\end{array}$ \\
\hline stress patterns & occurrences & rate & occurrences & rate \\
\hline$/(-) 10 /$ & 170 & $95.5 \%$ & 111 & $68.5 \%$ \\
\hline$/(-) 100 /$ & 7 & $3.9 \%$ & 49 & $30.2 \%$ \\
\hline$/(-) 1000 /$ & 1 & $0.6 \%$ & 2 & $1.3 \%$ \\
\hline
\end{tabular}

Table 4: Match rate results between oral data and Italian stress patterns

Results show that Italian words which are stressed on the penultimate syllable are also mainly stressed on the penultimate one by English speakers (95.5\%). Few cases of antepenultimate stressing are attested (3.9\%). The results turn out to be different when only Italian words with an antepenultimate stress are taken into account because it appears that the /(-)10/ stress pattern is still the preferential one $(68.5 \%)$ but the antepenultimate stress pattern is far more represented (30.2\%) than concerning Italian words that are stressed in /(-)10/. This meaningful difference demonstrates that English speakers might be sensitive to the original stress patterns and, more generally, to the phonological properties of source languages (here Italian). Indeed, some speakers tend to reproduce the original stress patterns (either /(-)10/ or /(-)100/). However, those results cannot be fully interpreted if no clear-cut separations are drawn, based on the speakers' command of Italian. As a matter of fact, this linguistic ability criterion is also a determining factor in the reproduction of corresponding Italian stress patterns. The next part re-interprets these results alongside this new parameter.

\subsubsection{Results based on speakers' linguistic abilities in Italian}

Four English speakers out of seven have no linguistic notions concerning the Italian language, have never studied it nor been exposed to it. Each of them pronounced the 50 Italian words and 6 items - that is 194 tokens (101 concerning /(-)10/ items and 93 concerning /(-)100/ ones - could not be used. 


\begin{tabular}{|l|l|l|l|l|}
\hline & \multicolumn{2}{|l|}{$\begin{array}{l}\text { Italian words in } \\
\text { 10/ }\end{array}$} & $\begin{array}{l}\text { Italian words in } \\
\text { 100/ }\end{array}$ \\
\hline stress patterns & occurrences & rate & occurrences & rate \\
\hline$/(-) 10 /$ & 95 & $94 \%$ & 73 & $78.5 \%$ \\
\hline$/(-) 100 /$ & 5 & $5 \%$ & 19 & $20.4 \%$ \\
\hline$/(-) 1000 /$ & 1 & $1 \%$ & 1 & $1.1 \%$ \\
\hline
\end{tabular}

Table 5: Match rate results between linguistically naïve speakers' productions and Italian stress patterns

The majority of Italian words that are stressed in /(-)10/ are also stressed on the penultimate syllable by English speakers even though they do not have any linguistic abilities concerning the Italian language. These results are not surprising because it appears that most $<\mathrm{VCV}>>$ words of foreign origin in English are stressed that way. This point will be dealt with later. The difference is more meaningful concerning Italian words that are stressed in $/(-) 100 /$ because English speakers tend to stress the penultimate syllable (78.5\%) all the same rather than the antepenultimate one (20.4\%). If global results only related to those four linguistically naïve speakers are pooled together, it is worth noting that they strongly stress the penultimate syllable when faced with an Italian word no matter its stress pattern in Italian (86.6\%) and that the antepenultimate stress is quite rare (12.4\%). Only $20 \%$ of /(-)100/ Italian words are stressed the same way by English speakers. Even if $/(-) 10 /$ is the preferential stress pattern, those linguistically naive speakers seem nevertheless to be slightly sensitive to the /(-)100/ Italian stress pattern because one word out of five is stressed according to the Italian stress pattern.

37 If English speakers with linguistic notions in Italian are now considered, the results significantly change. These three speakers generated 146 exploitable tokens (with 77 concerning Italian words in /(-)10/ and 69 concerning Italian words in /(-)100/).

\begin{tabular}{|c|c|c|c|c|}
\hline \multirow[b]{2}{*}{ stress patterns } & \multicolumn{2}{|c|}{$\begin{array}{l}\text { Italian words in /(- } \\
\text { )10/ }\end{array}$} & \multicolumn{2}{|c|}{$\begin{array}{l}\text { Italian words in /(- } \\
\text { )100/ }\end{array}$} \\
\hline & occurrences & rate & occurrences & rate \\
\hline /(-)10/ & 75 & $97.4 \%$ & 37 & $53.6 \%$ \\
\hline$/(-) 100 /$ & 2 & $2.6 \%$ & 31 & $44.9 \%$ \\
\hline /(-)1000/ & 0 & $0 \%$ & 1 & $1.5 \%$ \\
\hline
\end{tabular}

Table 6: Match rate results between initiated speakers' productions 
Concerning /(-)10/ Italian words, figures are roughly equivalent with a $97.4 \%$ match between Italian stress patterns and what English speakers actually produce. It appears that, whatever the level of linguistic requirements speakers may possess, they tend to stress Italian words on the penultimate syllable. However, a significant tendency emerges concerning the results with /(-)100/ Italian words. Indeed, initiated speakers better reproduce the antepenultimate Italian stress (44.9\%) than speakers with no prior notions in Italian (20.4\%). They are more familiar with the Italian stress system but may also be more sensitive to the reproduction of Italian phonological principles through the borrowing process.

The global results concerning these three initiated speakers consequently modify the tendency that was previously observed for linguistically naïve speakers. The total rate for antepenult stress amounts to $22.6 \%$ (versus $12.4 \%$ for non-initiated speakers). Though probably not a conscious phenomenon, it nevertheless indicates that initiated speakers have developed intuitions concerning the way Italian words are stressed. Unsurprisingly, the highest stress match rate is found among English speakers who were exposed to Italian, even over a very short period of time, as it enables them to reproduce original stress patterns more satisfactorily ${ }^{18}$.

\begin{tabular}{|l|l|l|l|}
\hline & $/(-) 10 /$ & $/(-) 100 /$ & $/(-) 1000 /$ \\
\hline global & $82,3 \%$ & $16,8 \%$ & $0,9 \%$ \\
\hline non-initiated speakers & $86,6 \%$ & $12,4 \%$ & $1 \%$ \\
\hline initiated speakers & $76,7 \%$ & $22,6 \%$ & $0,7 \%$ \\
\hline
\end{tabular}

Table 7: Overall results related to initiated and non-initiated speakers

\section{Discussion}

41 The study of the stress patterns of Italian loanwords in English pronouncing dictionaries clearly demonstrates that Italian loanwords massively reproduce corresponding Italian stress patterns whether primary stresses are located on the final, penultimate or antepenultimate syllable. Nevertheless, the results also confirm that the preferential stress pattern in Italian is /(-)10/ and, consequently, through the preservation of this Italian stress pattern, many penultimate stress patterns are attested in English. Thus, in $<\mathrm{VCV} \#>$ structures, the English language adopts Italian lexical items, as well as their stress patterns.

42 The oral test, experimented on native English speakers, has led to the following conclusion: English speakers massively stress Italian words on the penultimate syllable whatever the original Italian stress patterns. However, speakers with some knowledge of Italian reproduce more faithfully original Italian stress patterns and the observation of their stressing concerning the Italian items that are stressed in /(-)100/ confirms that the 
more they grow accustomed, the more they stress in accordance with Italian stress principles. Those conclusions are to be drawn with a measure of caution, because firstly, there were few recorded speakers, and secondly, it has been difficult to determine the degree of fluency of initiated speakers in Italian who might have been biased concerning the pronunciation patterns. Yet it is noteworthy that the more accustomed the speakers are to Italian, the more faithful they are to the Italian stress patterns. One should also keep in mind that those of the informants who were skilled in Italian had only been exposed to it at school and for a very brief period of time (up to one year). Generally speaking, it seems quite obvious that bilingual speakers had integrated Italian loanwords into their English lexicon. If this were not so, this close-to-perfect stress match would not have been possible and would not have been so well reflected by dictionaries. Before being attested in English dictionaries, these loanwords may firstly be used by a community of bilingual speakers hence their stress patterns would remain stable in English. Therefore, these bilingual speakers would not only integrate a new word into the English lexicon, but also its stress contour.

43 This influx of Italian loanwords in English, adopted with their original stress characteristics, has had a major influence on the stressing of foreign words in general. Considering that most Italian words are stressed on the penultimate syllable, and that the stress preservation principle implies that Italian loanwords are consequently stressed in / (-)10/ in English as well, French phonologists postulated the existence of a pedagogical stress rule, called the "Italian rule", that states that words ending by an alveolar consonant (except $<\mathrm{l}>$ and $<\mathrm{r}>$ ) and followed by a pronounced vowel are stressed on the penultimate syllable (see J.-M. Fournier 2010 amongst others). This rule does not only apply to Italian loanwords because the segmental characteristics of it also account for words of other origins such as Spanish, Japanese or Arabic loanwords. However, this stress rule is labelled the "Italian rule" because the vast majority of words, whose stress patterns are accounted for by this rule, are derived from Italian. This stress rule is in fact reductive as it is limited to segmental considerations, but its labelling which makes reference to etymological considerations, paves the way for the role of etymology in the stressing of loanwords in English. Indeed, syllable weight has long been considered as the fundamental factor in the stressing of loanwords, but, it appears that etymology might be determining as Church (1985) put out:

"It is clear (...) that the stress of Italian loans is not dependent on the weight of the penultimate syllable (...) I believe that speakers of English adopt what I like to call a pseudoforeign accent. That is, when speakers want to communicate that a word is non-native, they modify certain parameters of the English stress rules in simple ways that produce bizarre "foreign sounding" outputs".

Church (1985) stated that syllable weight could not account for the stressing of loanwords in English and that there seemed to exist a preferential stress pattern used by native English speakers that would be an indicator of the foreign character of words. This hypothesis has already been investigated concerning French loanwords (P. Fournier 2013 and 2016) and it turns out that the introduction of French loanwords in English reshaped the English stress system with the Romance and Germanic principles that merged into one single stress system (J.-M. Fournier 2007). The introduction of French loanwords has created a stress sub-system in English because the French final demarcative stress with primary stress mainly being located on the last syllable has been adopted as an indicator of the French origin of words $^{19}$. 
The stressing of French loanwords constitutes a unique case within the English stress system. We believe, however, that the introduction of Italian loanwords alongside with the stress preservation principle has also deeply modified the stressing of loanwords in general. Etymology should thus be perceived as a fundamental factor in stress assignment. Hundreds of Italian words with penultimate stresses integrated English. Then, this penultimate stress pattern was felt to "sound" Italian and it seems that English speakers adopted this /(-)10/ stress pattern to all loanwords with $\left\langle\mathrm{VCV}>\right.$ structure $^{20}$ in English whatever their origin may be. The analysis of oral data confirms this fact because when facing foreign words, "naïve" speakers will mainly opt for /(-)10/ which is the preferential stress pattern for loanwords but that has also become a way to identify them. Italian loanwords might have originated and developed the /(-)10/ stress pattern as a phonological indicator of the foreign character of loanwords in English in <VCV\#> segmental structures, which are mostly recognised as foreign segmental structures.

\section{Conclusion}

The study of the stress patterns of Italian loanwords in English dictionary sources shows a stress preservation principle between Italian and English. The possible introduction of Italian loanwords in English by bilingual speakers might have influenced the stressing of loanwords in general because the /(-)10/ stress pattern, massively imported from Italian, seems to be the preferential one used by native speakers to stress foreign words no matter what their origin may be (except French). Further oral investigations are needed concerning the stressing of foreign words other than Italian to prove it.

\section{BIBLIOGRAPHY}

Arrizi, A. \& Robert, P. (1999), Le Robert \& Signorelli. Dictionnaire français-italien / italienfrançais, Le Robert.

Borrelli, D. (2002), Raddoppiamento Sintattico in Italian. A Synchronic and Diachronic Crossdialectal Study. New York, London: Routledge.

Calabrese, A. \& Wetzels, L. (2009), Loan Phonology, Amsterdam: John Benjamins.

Church, K. (1985), “Stress Assignment in Letter-to-Sound Rules for Speech Synthesis”, The Journal of the Acoustical Society of America, 78 (S1).

D'Imperio, M. \& Rosenthall, S. (1999), “Phonetics and Phonology of Main Stress in Italian”, in Phonology 16, 1-28.

Fournier, J.-M. (2007), "From a Latin Syllable-Driven Stress System to a Romance Versus Germanic Morphology-Driven Dynamics : in Honour of Lionel Guierre”, in P. Carr \& P. Honeybone (ed.), English Phonology, Language Sciences 29, 218-236.

Fournier, J.-M. (2010), Manuel d'anglais oral, Paris : Ophrys. 
Fournier, P. (2013), «L'accentuation des emprunts français en anglais britannique et américain », Annales de l'Université de Craïova - Série langues et littératures romanes, AN XVII, Nr.1, 2013, Craïova : Universitaria, 105-129.

Fournier, P. (2016), « Nouvelles perspectives sur l'accentuation des emprunts en anglais contemporain », Itinéraires, 2015-2, Stumbling blocks. Entraves et obstacles aux circulations. Approches pluridisciplinaires. Sous la direction de M. Lévêque et C. Parfait (consultable en ligne : http://itineraires.revues.org/2827).

Fournier, P. (to appear), « Transcription et formalisation de l'accentuation des mots italiens en anglais contemporain », Corela.

Friesner, M. (2009), “The Adaptation of Romanian Loanwords from Turkish and French”, Loan Phonology, edited by A. Calabrese \& L. Wetzels, 115-130.

Haspelmath, M. \& Tadmor, U. (2009), Loanwords in the World's Languages: A Comparative Handbook, Mouton de Gruyter.

Jones, D. (2011), Cambridge English Pronouncing Dictionary (18 ${ }^{\text {th }}$ edition), Cambridge: Cambridge University Press.

Kentowicz, M. \& Sohn, H.-S. (2001), “Accentual Adaptation in North Kyungsang Korean”, Ken Hale: A Life in Language, ed. by M. Kentowicz, Cambridge, Mass.: MIT Press, 239-270.

Kramer, M. (2010), The Phonology of Italian, Oxford: Oxford University Press.

Oxford English Dictionary online version (last consulted: March $2^{\text {th }} 2016$ ).

Pinnavaia, L. (2001), The Italian Borrowings in the Oxford English Dictionary, Bulzoni Editore Edition.

Sabatini, F. \& Coletti, V. (2005), Dizionario della Lingua Italiana, Milano : Rizzoli-Larousse.

Schultz, J. (2013), Twentieth Century Borrowings from French to English : Their Reception and Development, Cambridge Scholars Publishing.

Svensson, A.-M. (2001), “Germanic vs French Stress in Disyllabic Loan Words in English”, Studies in Honour of Göran Kjellmer, Gothenburg Studies in English 81, 123-129.

Svensson, A.-M. (2004), "On the Stressing of French Loanwords in English”, Amsterdam Studies in the Theory and History of Linguistic Science Series 4, volume 252, 225-234.

Svensson, A.-M. (2007), “On the Stress-Shifting of Polysyllabic French Loans in English”, Topics in English Linguistics, volume 53, 93-104.

Thornton, A.M., Iacobini, C. \& Burani, C. (1997), BDVDB: Una base di dati sul vocabolario di base della lingua italiana. (BDVDB: A database for the Italian basic dictionary). Roma: Bulzoni.

Wells, J.C. (2008), Longman Pronunciation Dictionary (3 $3^{\text {rd }}$ edition), London: Longman.

\section{APPENDIXES}




\section{Annex: Corpus of Italian loanwords in English (309 items)}

abbate (abate), acciaccatura, affettuoso (affet(t)uoso), agitato, Aleatico (aleatico), alla breve ( breve $^{21}$ ), alla prima (prima), altissimo, amorino, amoroso, andantino, appoggiatura, archipelago ( arc(h)ipelago), autostrada, bailo, balcony (balcone), ballabile, ballata, ballerina, bambino, barbone, battuta, beccafico, bel paese, ben trovato (bentrovato), bottega, bravo, bravura, broc (c)oli (broccolo/broccoli), bucchero, bumbelo/bumbolo (bombola), Calabrese (calabrese), campanile, cannelloni (cannellone/cannelloni), cantabile, cantata, cantino, canzona (canzone), canzone, capitano, capo, cappuccino, Carbonaro (carbonaro), carissima (carissimo), casino/ cassino (casino), cassata, cassone, castrato, cavatina, cembalo, centesimo, chiaroscuro, chitarrone, cicerone, clarino, coda, col(l)arino (collarino), coloratura, commendatore, con amore (amore), con sordino (sordino), concertino, contadina (contadino), contadino, cortile, crotalo, cupola, cymbalo ( cembalo), da capo (dac(c)apo), dado, del credere (delcredere), disinvoltura, diva, dogana, dolce vita (dolcevita), doloroso, Duce/duce, energico, espressivo, evirato, evviva, falso bordone ( falsobordone), famoso, fata Morgana (fatamorgana), fermata, fettuccine (fettuccina), fico, finale, fioritura, fiumara, flautato, flautino, flauto, fondaco, formatore, fortissimo, frate, frottola, fugato, furore, generalissimo, giallo antico (antico), giga, giocoso, girandola, giro, gola/gula (gola), gondola, gradino, graffito, granita, grano, gregale/grigale/grecale (gregale), Grignolino ( grignolino), grissino, grosso modo, illustrissimo, impresa, imprimatura/imprimitura ( imprimitura), improvisatore (improvvisatore), inamorata (innamorato), inamorato ( innamorato), incognita, incognito, intarsiatore, intonaco/intonico (intonaco), isolato, jettatore ( iettatore), jettatura (iettatura), ladino, lamentoso, lava, lazzaro, lazzarone, legato, letterato, lettiga, linguine (linguina), lira, literato (letterato), loco, macaroni (maccherone), maestoso, maestrale, magnifico, mandola, maraschino, marcato, marchesa, marchese, Martini (martini), mela-rosa (melarosa), mezzani (mezzano), mezzo-soprano (mezzosoprano), minestrone, moderato, monsignore ${ }^{22}$, moscato, motoscafo, musico, muta, nespola, neutrino, obbligato, oboe, oime, ombrellino, opera, osso buco (ossobuco), ostinato, ottava, ovolo (ovolo/ovulo)), padrone, pallone, panettone, papabile, partita, pastorale, pecorino, peperino, pepperoni (peperone), pergola, pianino, pianissimo, piccolo, Pietà/pietà (pieta), pifferaro, piffero, pizzicato, poco, podere, pomposo, porfido, portantina, pozzolana, presa, prestissimo, prima ballerina (ballerina), primo, provolone/Provolone (provolone), pulvino, Questore/questore (questore), Questura/questura (questura), rapido, ravioli (raviolo), recitativo, replica, ricercare, ricercata (ricercato), rigatoni (rigatone/rigatoni), rione, ripresa, risoluto, ritenuto, riva, romanità/Romanità (romanita), Romano (romano), rosso antico/ Rosso Antico (antico), rotolo, salami (salame), salita, salone, sambuc(c)a/Sambuc(c)a (sambuca), sandolo/sandalo, salto mortale (mortale), scaldino, scallopini (scalopina), scena, scopa, scordatura, scorzonera (scorzanera), scudo, semola, semolina/semoulina/semolino (semolino), semplice, serenata, sestina, sforzato, sfumato, signora, signorina, sindaco, solfatara, solo, sonata, sonatina, sopranino, soprano, sostenuto, sotto voce (sottovoce), spadona (spadone), speronara ( speronare), spiccato, spinone, sposa, sposo, sprezzatura, spumoni (spumone), Squadrone ( squadrone), staccato, stile concitato (concitato), stile rappresentativo (rappresentativo), stoccado (stoccata), strac(c)hino (stracchino), strepitoso, stufa, subito, tagliarini (taglierini), tartana, tempera, tenebroso, tenore, terreno, terribilità (terribilità/terribilita), terzina, tessitura, timpani/tympani (timpano), toccata, tombarolo, tombolo, tondino, tornese, tortellini (tortellino), trabac(c)olo, tremolo, Triplice/triplice (triplice), tromba marina (marina), tuba, tufa (tufo), uomo universale (universale), veduta, vettura, vetturino, vibrato, villeggiatura, villino (vil(l)ino), violino 
piccolo (piccolo), violone, virtuosa (virtuoso), virtuoso, vivace, voce, volcano (vulcano), zeppole ( zeppola), Zingano (zingaro), Zingaro (zingaro), zita, zucchini (zucchino), zuf(f)olo (zufolo).

\section{NOTES}

1. I would like to thank Sophie Herment and Stephan Wilhelm for their constructive comments.

2. A loanword is considered to be direct when directly imported in English from Italian without any intermediate language which might have phonologically influenced its resulting stress pattern.

3. This criterion also leads us to reject loanwords with <-VCiV\#> structures because <iV> sequences may be perceived as monosyllabic in Italian, whereas, in English, these sequences are disyllabic. This discrepancy might affect the syllabic treatment of stress patterns.

4. Indeed, if both words are stressed on the penultimate syllable, it is impossible to determine whether it is due to the presence of pre-final consonant clusters or to the preservation of the stress pattern from the source language to the target language.

5. The items in bold letters between brackets correspond to the corresponding Italian terms when different from their English counterparts.

6. Surprisingly, the <e\#> of Bolognese is mute in the OED but it appears that it can also be pronounced as a variant in the EPD. However, the criteria-based approach is only applied on the OED database and that is the reason why this loanword is not integrated into the final corpus.

7. In a few cases, the mute final <e> criterion and the lack of phonetic transcription may be cumulative, but, without any phonetic details, it is hard to determine.

8. Loanwords whose orthographic structures attest final <e\#> may be pronounced in two different ways. There are few cases, but it appears that the pronunciation of these loanwords reflects a higher degree of nativization, and thus, $<\mathrm{e} \#>$ is not pronounced, or, on the contrary, the pronunciation is faithful to the Italian origin, and then, it turns out that <e\#> is pronounced and has a vocalic, and therefore a syllabic, status. Only the second option is taken into account in our analysis (examples in the EPD : Calabrese, pastorale).

9. The identification of corresponding Italian words has to be carefully carried out because stress has a distinctive function in Italian and two lexical words may only be distinguished by stress location. For example, subito is either the past participle of subire or an adverb meaning "fast, quick". This lexical difference is marked in Italian by distinct stress patterns. English only borrowed the Italian adverb. Corresponding Italian words were carefully selected.

10. The results concerning the stress match investigation in Italian and English are slightly different from those that are found in previous studies (P. Fournier 2016 ; P. Fournier to appear). Indeed, the status of syneresis is differently approached in this article, and loanwords that undergo this process have not been integrated into the final corpus, as previous studies had done. However, the general conclusions that can be drawn from this analysis are not modified.

11. The Italian loanword rosso antico displays a singular stress pattern in the OED with two primary stresses ('rosso an'tico). However, only the second term antico is under scrutiny because the complete loanword cannot be found in Italian dictionaries.

12. The choice of "match" as a term that suggests both the notions of comparison and transfer, perfectly illustrates the source language / target language transition. The table is to be understood that way. As a consequence, the Italian term is located on the left and the corresponding Italian loanword in English is on the right. The arrow symbol illustrates the borrowing transfer.

13. The number (3) means that the associated stress pattern is attested in the three English dictionary sources. On the contrary, if the abbreviation of a single source is between brackets, 
then, this loanword and therefore its stress pattern are only attested in the corresponding source.

14. This also corresponds to the typical stress pattern of an English compound.

15. The (US/GB) mention means that the variation process is the same in both varieties of English.

16. Both meanings of the Italian word, which then has a distinguished stress pattern, are attested in the OED. But it does not alter the /(-)10/ stress pattern in English.

17. This result concerning the /(-)1000/ stress pattern is not significant because there are many words in the list containing less than four syllables.

18. The degree of familiarity of initiated speakers with selected Italian words is impossible to determine, though it might also be a significant parameter affecting the experiment.

19. The stressing of French loanwords is to be dealt with carefully because it appears that it is subject to varietal considerations (British English and American English) as well as syntactical ones (mainly the common noun / proper noun distinction) (see P. Fournier 2016).

20. It appears that this phenomenon can be extended to all words with $\angle \mathrm{VCV} \#>$ structures and is not restricted to specific consonants.

21. In some cases, only the last Italian lexical item was found in Italian dictionaries. However, as long as primary stresses in English are assigned on the second lexical element, those items are included into the final corpus. This, nonetheless, questions the limits between compounding and independent lexical units.

22. Monsignore is not attested as a main entry in the OED. It is a variant spelling form of the main entry which is Monsignor. However, the phonetic transcription of Monsignore shows that in English the final vowel is realized and, therefore, it is integrated to the final corpus.

\section{ABSTRACTS}

Italian loanwords in English are stressed according to their original Italian stress patterns in $<\mathrm{VCV} \#>$ structures. The lack of autonomy of the English stress system, which is only rendered by few stress variants, demonstrates that English faithfully reproduces the phonological properties of Italian stress. When dictionary-based data is compared with oral data, collected by means of tests carried out on native English speakers, the results show that English speakers are sensitive to Italian stress assignment. Indeed, stress match increases with the speakers' exposure to Italian. The introduction of Italian loanwords might have created a sub-system in English with a specific stress pattern that might apply to foreign words with $<\mathrm{VCV}>>$ structures.

Les emprunts italiens en anglais reproduisent à plus de $95 \%$ le schéma accentuel de la langue source dans les structures en $\langle\mathrm{VCV}\rangle>$. La faible autonomisation du système anglais, qui se traduit principalement par l'apparition de quelques variantes accentuelles, démontre que l'anglais emprunte non seulement une structure lexicale, mais également des données phonologiques de cette même structure. Ces données dictionnairiques, confrontées à des données orales obtenues au moyen de tests réalisés sur des locuteurs anglophones, permettent de formuler des hypothèses sur la perception qu'ont les locuteurs anglophones des mots italiens en particulier, avec un taux de correspondance augmentant en fonction du degré d'exposition des locuteurs à l'italien. L'introduction des mots italiens en anglais et la conservation du schéma accentuel de la 
langue source pourraient être à l'origine de la création d'un sous-système accentuel à l'œuvre en anglais s'appliquant à tous les termes étrangers en $<\mathrm{VCV} \#$.

INDEX

Keywords: lexical stress, Italian loanwords, Loan Phonology, English pronunciation dictionaries, English native speakers' perception.

Mots-clés: accentuation lexicale, emprunts italiens, dictionnaires anglais de prononciation, perception locuteurs anglophones.

\section{AUTHOR}

FOURNIER PIERRE

(Pléiade EA7338) - Paris 13 University 